\title{
Edukační přínos zoologických zahrad: etická reflexe
}

\author{
Marie Hrdá \\ Envigogika 16 (1) - Recenzované články / Reviewed Articles \\ Published/ Publikováno 15. 09. 2021
}

DOI: $10.14712 / 18023061.622$

\begin{abstract}
Abstrakt
Jedním z primárních cílů zoo je vzdělání a výchova v ekologii a ochranářství. Tento příspěvek $\mathrm{k}$ proměně lidského přistupu $\mathrm{k}$ přírodě a zastavení vymírání druhů, který má nějakým způsobem legitimizovat držení divokých zviřat v zajetí, je kritiky zpochybňován. Jak tomu je se vzdělávacím př́nosem ve skutečnosti, mohou ukázat výzkumy. Text se věnuje výsledkům výzkumů o vzdělávacím prínosu zoo a jejich analýzám. Předpokládá se, že návštěva zoo by měla přispět k pro-environmentálnímu cítění, ochranářskému étosu, postoji a chování, ke gramotnosti v biodiverzitě a dalším. Závěry výzkumů jsou ale prozatím přinejmenším nejednoznačné. Cílem příspěvku je v kontextu těchto nejnovějších výzkumů poukázat na další relevantní faktory, které mohou ovlivňovat postoje lidí, a na prípadný potenciální edukační prínos zoologických zahrad v jiných oblastech.
\end{abstract}

\begin{abstract}
One of the zoo's primary goals is education and training in ecology and conservation. This contribution to changing the human approach to nature and halting the extinction of species, which should somehow legitimize the keeping of wild animals in captivity, is being challenged. Research can show the reality of educational benefits. The text deals with the results of research on the educational benefits of zoos and their analyses. It is assumed that a visit of the zoo should contribute to pro-environmental sentiment, conservation ethos, attitudes and behaviours, biodiversity literacy and more. However, conclusions from the research are so far at least ambiguous. The aim of this paper is to point out, in the context of this latest research, other relevant factors that may influence people's attitudes and the potential educational benefits of zoos in other areas.
\end{abstract}

\section{Klíčová slova}

environmentální vzdělávání; návštěvníci zoo; výzkum vlivu; ochranářský postoj; zvířata v zajetí

\section{Key words}

environmental education; zoo visitors; research of visitor's impact; conservation attitude; captive animals 


\section{Úvod}

$\checkmark$ Česku tradičně patřila a i dnes patří návštěva zoo ${ }^{1}$ mezi tradiční školní výlety. Dưraz na vzdělávací potenciál této návštěvy se klade jak ze strany škol, tak zoologických zahrad. Zoologické zahrady se snaží školy přitáhnout a zároveň jim ulehčit tím, že vytvářejí a nabízejí programy pro školy a školní skupiny. Nabízeny jsou např. prohlídky s průvodcem, aktivní výukové programy, pracovní listy, některé zaměřené na pozorování zviřat, soutěže apod. Zoologické zahrady mívají pro děti (nejen při organizované školní návštěvě) "kontaktní zvířata, která jsou součástí zážitkového vzdělávání. Proč existuje nepřehlédnutelná snaha spojit zábavu s výchovou?

Původní motiv vyl vyjádřen Davidem Hancocksem (2001), který napsal, že vzdělání je jediné ospravedlnění pro zoo, proto jen těm zoo, které jej nějak podporují, by mělo být dovoleno přežít. $K$ tomu se přidal motiv, který se u akreditovaných zoo po celém světě vyjadřuje $\checkmark$ presvědčení, že vzdělávání je centrální součást ochranářství a že když se masy naučí pečovat o zviŕata, se kterými se střetly v zoo, budou zároveň podporovat i ochranu divočiny (Braverman, 2013). Učení $v$ zoo by mělo být snadné, protože jde o spojení se zábavou, a co nás baví, to nás motivuje. I to je důvod, proč se do něj vkládají velké naděje. Mohou tyto naděje být naplněny?

Pro mnohé lidi ve velkých městech, kde mají nedostatek kontaktu se zvíraty, je zoo hlavním místem setkání s nimi (Bulbeck, 2005). Zoo navštíví velká část populace. AZA uvádí ročně více než 183 milionů návštěv v USA (AZA, 1997-2021), WAZA (2021) uvádí více než 700 mil. po celém světě. $\vee$ ČR to bylo v r. 2019 více než 5,5 mil. návštěv. Otázka, čemu nás zoo učí, se prizmatem této reality stává velmi naléhavou. Jaký typ vztahu ke zvíratům a $k$ př́rodě podporuje? Jaký životní styl? Mohou být zoo impulzem ke změně hodnot a postojů, $\mathrm{k}$ vytvoření respektu $\mathrm{k}$ prírodě?

Nejprve se zaměřím na ideje a předpoklady, na nichž stojí obhajoba etického příspěvku zoo, a jímž je právě př́nos pro environmentální vzdělávání, uvedu studie, které se snaží vzdělávací př́nos potvrdit, nebo ukázat, co vede $\mathrm{k}$ lepšímu výsledku, představím v literatuře uváděné negativní dopady návštěvy zoo, abych nakonec skrze filosofickou reflexi načrtla další potenciální výchovné působení. Veškerá uváděná kritika zoo v literatuře se vztahuje na zoo jako kulturní instituci. Některé konkrétní zoo se již velmi proměnily. Není ani kritikou pečovatelů o zviŕata, kteří se často s velkým nasazením a obětavostí starají o svoje svěřence, ani kritikou návštěvníků, pro něž může být návštěva zoo důležitým radostným momentem $v$ životě.

\section{Zábavný výlet jako vzdělávací aktivita}

$\checkmark$ nedávné historii se náš vztah ke zvíratům alespoň částečně proměnil. Byli jsme svědky jak rozšíŕení velkochovů a krutých praktik v zacházení s hospodářskými zvíraty, tak zrodu filozofických proudů a veřejných hnutí, které se těmto praktikám a způsobům, jak zviŕata užíváme, resp. zneužíváme, staví na odpor. Pozornost veřejnosti se obrátila rovněž

${ }^{1} \mathrm{~V}$ celém tomto textu beru $\mathrm{v}$ úvahu akreditované zoo $\mathrm{v}$ organizacích EAZA (European Association of Zoos and Aquaria), AZA (American...), WAZA (World...)., tedy ty, jejichž kvalita péče o zvířata by měla být zaručena. 
$\mathrm{k}$ divokým zviřatům $\mathrm{v}$ lidské kultuře $\mathrm{s}$ otázkou, zda máme právo je držet $\mathrm{v}$ zajetín . Poté, co v 70. letech 20. století začalo sílit hnutí za práva zvírat nebo také hnutí osvobození zvířat, objevila se pochopitelně také veřejná debata o etické ospravedlnitelnosti zoo. Mnozí požadovali zrušení zoo (Jamieson, 1985), nebo přinejmenším radikální reformu (Hancocks, 1995), či přeměnu na útulky (Kagan, 2016, Gruen, 2016). Především zastánci práv zviŕat považuji držení zvířat $v$ zoo za eticky neospravedlnitelné (Regan, 1995). Mezi současné kritiky patři např. organizace PETA, která zoo viní ze zneužívání zviŕat pro naši zábavu:

„Zoo, které odsuzují cítící, inteligentní a sociální zvířata k životu v klecích pro naše chvilkové rozptýlení a pobavení, nejsou o moc lepší. Mnohá zvírata v zoo jsou extrémně znuděná, trpí depresemi a jsou zbavena všeho, co je pro ně přirozené a důležité, doslovně ztrácejí rozum - tento stav se nazývá "zoochóza". Zvíratata trpící zoochózou vykazují neurotické chování jako přecházení, točení se a kývání hlavou. Rovněž se mrzačí, jsou přehnaně agresivní, házejí výkaly a projevují další abnormální chování, které se ve volné prírodě nevyskytuje." (PETA, 2021)

Zoo, u nichž se předpokládá vysoká úroveň péče o zviřata, jsou organizované pod zastřešujícími organizacemi, které udělují tzv. akreditace, tedy certifikát zaručeného stupně kvality. Zoo skrze tyto organizace odpověděly na kritiku jak důrazem na záchranu vymírajících druhů a na edukační potenciál, tak i změnami v samotné organizaci zoo (Smith, Broad \& Weiler, 2008). Vzdělávání ( $v$ nejširším slova smyslu) se uvádí mezi tzv. čtyřmi cíli, mezi nimiž zábava byla až tím posledním (Maple et al., 1995), a spíše měla hrát roli katalyzátoru pro učení. Dalšími cíli jsou záchrana druhů a vědecký př́nos. Dnes je vzdělávací cíl stále více zdůrazňován a zmiňován téměř ve všech prohlášeních akreditovaných organizací. Podle Stausse (2020) se návštěva zoo považuje za neformální a free-choice vzdělávání, které kromě informací může měnit chování a citovou vazbu $\mathrm{k}$ přírodě. Přesto protesty proti chovu zvířat $\mathrm{v}$ zoo neustávají. Jsou poháněny přesvědčením, že přes všechny (byt́ upřímné) snahy, nemůže být welfare některých zvířat v zajetí nikdy dostatečné (Bekoff, 2007; Clubb, \& Mason, 2003), že mnoho zvírat $v$ zoo strádá, nebo že se zoo proměnily jen naoko, ale skutečné ochranářství a vzdělání „nedodávaji”" (Marino, 2016).

\section{Vzdělávací potenciál a očekávání odborníkư}

Na otázku, $v$ čem a jak by měla zoo vzdělávat, která je důležitá pro postavení zoo na veřejnosti, se odpověd' proměnila opravdu markantně. Zatímco $v$ minulosti byl důraz kladen na informace o zviŕatech a jejich biotopech (znalosti), nyní jsou to podle studie Readinga a Millera (2007) především pozitivní hodnoty a postoje ke zviŕatům a ochraně prírody ${ }^{3}$, a tím k aktivnímu prístupu. Za érou informačních tabulí stála naděje, že informovanost povede k pro-environmentálnímu jednání (Staus, 2020). V tomto konkrétním případě měly znalosti podpořit pozitivní vztah ke zvíratům, přinést uvědomění, které dále povede k lásce ke zviŕatům a prírodě, a tím také $\mathrm{k}$ zainteresovanosti na jejich ochraně. Vytvoření kladného postoje ke zviŕatům a vliv informace je však v tomto procesu mnohem komplikovanější. Učení je výsledek individuální kombinace minulých zkušeností, stávajících znalostí, motivace a zájmů

\footnotetext{
${ }^{2}$ V článku používám termín „V zajetí", protože tak je použíaán ve zdrojích, z nichž čerpám ("captivity"). V současnosti se v některých zdrojích používá "v lidské péči” kvůli negativním konotacím termínu "zajetí". Avšak tento pojem nečiní rozdíl mezi domestikovanými a divokými zvířaty. $\mathrm{K}$ podobné změně došlo již v 80.letech, kdy byly emocionálně zabarvené termíny příroda - zajetí nahrazeny nahrazeny termíny "in-situ" (aktivity zoo v cizích zemích na podporu ochrany přírody) a "ex-situ" (chov zvířat v zajetí). Viz Bravermann, 2014.

3 Užívám běžný český výraz "ochrana přírody", ačkoliv v anglosaském prostředí se užívá termín "ochrana divočiny", protože stále častěji bývá zdůrazňováno, že skutečná divočina již neexistuje.
} 
(Staus, 2020). Doložit, zda a jak funguje přenos informací, a jaký vliv má střetávání s původně divokými zviŕăty ve výbězích, by měly ukázat výzkumy.

Kritika zoo rovněž vytvořila tlak na posun v cílech vzdělávání. Její argument staví na premise, že pouhé informace o zviŕatech, jejich biotopech, stravovacích zvycích apod., nemohou eticky ospravedlnit držení divokých zviŕat v zajetí. Margodt $(2000$,$) a spolu s ním$ další, zdůrazňuje, že informace o biologii a etologii zviŕă můžeme totiž daleko snáze získat jinak, způsobem, který zvířata nepoškozuje (Margodt, 2000). Dokumentární filmy nám přirozený život zviŕat přibliží takříkajíc intimněji a pravdivěji, než kdybychom seděli celý rok před jedním výběhem v zoo. Proto, má-li držení zvířat v zajetí něco legitimizovat, musí zoo na návštěvníky působit jiným způsobem, než jak to dokáží informační materiály.

Z kritiky zoo vyplývá, že pod pojmem vzdělání se míní především potřebná změna $v$ lidských postojích a hodnotách. Což je zcela pochopitelné. Žijeme $v$ době bezprecedentní destrukce př́rody, při níž se na seznamu vyhynulých či vyhynutím ohrožených druhů množství položek rapidně zvyšuje. Informace, či vzdělání, které návštěva zoo zprostředkuje, by $v$ ideálním př́padě mělo vést $k$ uvědomění si souvislostí mezi naším životním stylem a poškozováním ekosystémů, k poznání zranitelnosti ekosystémů, a mělo by měnit i postoje a chování, zejména spotřebitelské vzory, vytvářet ochranářské postoje a podnítit empatii se zviŕraty (Bulbeck, 2010). Vzhledem k závažnosti situace (před níž odborníci varovali už před desítkami let), je každá taková změna vítaná.

\section{Cíle akreditovaných zoo}

Akreditované zoo přijaly představu o nutnosti rozšírit vzdělávací cíle za pouhé předání informací za své, a začaly vytvářet vzdělávací programy. Pro dokreslení, WAZA uváděla svoji představu o tom, jak mohou zoo přispět k ochraně prrírody v r. 2005 takto: „...skrze ovlivňování chování lidí a jejich hodnot, bude na vzdělání nahlíženo jako na důležitou ochranářskou aktivitu" (cit u Smith et al., 2008). WAZA předpokládala, že zoo může změnit u velmi rozsáhlého počtu návštěvníků jak znalosti a porozumění, tak také postoje, jednání a zapojení do ochranářských aktivit. (Smith et al., 2008). Novější doporučení ke vzdělávání z r. 2020 se opírá o hesla: láska, péče, ochrana, spolu, což konkrétně znamená: oslovit návštěvníky (láska), ukázat jim, že jde o jejich zájem (péče), informovat, co dělá organizace Wild Planet Trust (ochrana) a podnítit je k prripojení k aktivitám této organizace (spolu).

Doporučení (ze vzdělávací strategie) WAZA z r. 2020 zní takto:

„Vzdělávání v oblasti ochrany př́rody v zoologických zahradách a akváriích by se mělo zaměřit na: Rozvíjení znalostí a porozumění druhům, přírodě a př́nosu zoologických zahrad a akvárií k ochraně prírody. Podporu pozitivních vztahů, emocí, postojů, hodnot a empatie $\mathrm{k}$ druhům, prírodě a zoologickým zahradám a akváriím. Podporu úcty, obdivu, radosti, tvořivosti a inspirace ohledně druhů a prírody. Motivaci k proenvironmentálnímu chování, jednání a obhajobě druhů a prírody. Rozvoj vědeckých, technických a osobních dovedností spojených se zoologickými zahradami, akvárii a ochranou biodiverzity." (WAZA, 2020, s. 26)

Jak kritikové zoo, tak zastřešující organizace zoo se shodují na předpokladu, že výchova by měla vést ke změně v lidském chování, k ochotě proměnit svưj životní styl na méně poškozující, prípadně se zapojit do aktivní ochrany. Co to ale přesně je, není v literatuře, věnující se výzkumům těchto postojů, shoda. Některé z možných označení jsou: „pro-environmentální cítění $(. .$.$) , ochranářský étos (. .$.$) , ochranářské záměry (. .$.$) , ochranářské smýšlení$ 
(...), ochranářské pečování (...), ochranářské postoje a chování (...), environmentální záměry (...), gramotnost v biodiverzitě (...)" (Nygren \& Ojalammi, 2018, 64).4

Spor o oprávněnost a etičnost zoo pokračuje, a přispívá $k$ tomu i to, že nemáme na první pohled jasné důkazy o naplnění vzdělávacího cíle zoo. $Z$ přehledů stále pokračující devastace př́rody je totiž zjevné, že situace se vzhledem ke drancování př́rody významně nelepší. Zastánci i odpůrci zoo poukazují především na množství akreditovaných i neakreditovaných zoo a velké množství návštěvníků (viz údaje výše), přičemž mnozí zoo navštíví opakovaně (Hutchins et al., 2008). Pro obě strany z toho vyplývá, že potenciál působení na svoje návštěvníky mají zoo skutečně obrovský. Otázkou zưstává, zdaje je tento potenciál také využitý. Přihlédněme tedy nejprve $\mathrm{k}$ tomu, co o naplnění vzdělávacího cíle vypovídají výzkumy.

\section{Výzkumy efektu učení v zoo}

Jednou z prvních a v literatuře často uváděných studií je studie Stehena Kellerta z $r$. 1979. Podle této studie jsou návštěvníci dokonce méně vzdělaní než např. lovci či rybáři. I další výzkumy, které podnikl, vedly k podobným výsledkům - účastníci odcházeli se stejnými předsudky, s jakými do zoo přišli. Jen velmi málo lidí četlo informační tabule, nezůstali dlouho, aby sledovali chování zviŕat, byli motivováni především rodinnou zábavou, vzrůstal $\checkmark$ nich pocit nadřazenosti a návštěva zoo podněcovala $k$ antropomorfizování zviŕat. $V$ další studii v r.1997 Kellert konstatoval, že mnozí návštěvníci odcházejí ještě přesvědčenější o nadřazenosti nad přirozeným světem (cit. dle Jamieson, 1985; Acamphora 2008).

Mezi často citovanou studií je studie AZA (Falk et al., 2007), která měla za cíl dokázat pozitivní vliv zoo. Tato studie byla kritizována pro vážné metodologické chyby (Marino et al., 2010). Jednou z vytýkaných chyb bylo, že dlouhodobý efekt vzdělávání byl dokazován na skutečnosti, že po téměř roce byla necelá polovina dotazovaných schopná si vzpomenout na některé zvláštní zvíře či druh ze zoo.

Do dnešních dní vznikla celá řada dalších studií, většinou malých a zaměřených na určité konkrétní expozice, vzdělávací program, nebo tř́́du (např. Ballantyne, Packer, Hughes, \& Dierking, 2007; Barney, Mintzes, \& Yen, 2005; Mann-Lang, Ballantyne, \& Packer 2016; Martens, Hansart, \& Su, 2019). Celkovou odpověd' na vliv zoo na environmentální vzdělávání ale nemáme. Jednou z překážek zodpovězení otázky po vlivu zoo na změnu postojů, je notoricky známá obtížnost měření účinků učení a změn v chování. Někteří se domnívají, že účinek návštěvy zoo per se možné měřit není, protože informace a zkušenost jsou zpracovávány individuálně v závislosti na již existujících vědomostech a postojích. Do procesu učení vstupují také další faktory jako např. sociální kontext (Nygren \& Ojalammi, 2018). Jako nedostatek, který může zkreslovat výsledek výzkumu, je možné vidět i to, že výzkumy, které mají měřit ochranářskou změnu u dospělých, se obvykle zaměřují na činnosti jako recyklování, kupování ekologicky šetrných produktů, finanční příspěvky, petiční aktivity a podobně (Collins et al., 2019). To jsou sice pozitivní kroky, ale vzhledem k celkovému rozsahu ekologické krize se mohou zdát až banální (Nygren, Ojalammi, 2018).

Ponecháme-li stranou zmíněné obtíže měření účinků na chování, výsledky výzkumů, které se zaměřovaly na dlouhodobý vliv návštěvy zoo, mají tendenci demonstrovat, že je pouze malý. Existuje množství vysvětlení, proč tomu tak je. Vedle vlivu různých způsobů

\footnotetext{
${ }^{4}$ Pro-environment sentiment, conservation ethos, conservation intentions, conservation mindedness, conservation caring, conservation attitues and behaviour, environmental intentions, biodiversity literacy
} 
měření výsledků, si je možné vysvětlovat výsledky i tím, že zoo promlouvají k těm návštěvníkům, kteří už jsou přesvědčení (Smith et al., 2008). Možná jsou očekávání, že by jedna návštěva zoo ovlivnila dospělé svým ochranářským poselstvím, nerealistická (Balmford et al., 2007). Nebo potřebujeme longitudinální studie, jak se domnívá Chilla Bulbecková (2010).

Studie literatury z r. 2018 (Nygren, Ojalammi) uvádí, že k učení dochází za předpokladu, že návštěvník už je v ochranářství uvědomělý, návštěva probíhá v interaktivním a přirozeném uspořádání, zviřata jsou aktivní, či charismatická, dojde k nějakému kontaktu $s$ nimi, např. očnímu, návštěva je poznatelně delší a je tu podporující sociální kontext. Přesto tato studie uzavírá, že celková evidence o tom, která by dokládala, že se návštěvníci učí o ochranářství a biodiverzitě, či dokonce významněji, že toto učení vede ke změně chování, zůstává slabá. Nancy Staus v práci z r. 2020 shrnuje, že dle empirických studií, jsou zoo úspěšné $v$ podpoře pocitů péče a spojení $s$ př́rodou, avšak nepř́liš úspěšné $v$ podpoře proenvironmentálního chování (Staus, 2020). Studie týkající se kognitivních schopností mají rozporuplné výsledky. Jen některé studie uvádí nárůst vědeckých znalostí (které ale nejsou stěžejní pro ochranářství), jež posílily již existující znalosti (Staus, 2020). U školních dětí k tomu došlo s podporou vzdělávacího programu (Collins et al., 2019).

Část výzkumů ukazuje nepřekvapivé důvody, proč (alespoň podle některých) zoo seIhává ve výchově. Jde především o motivaci k návštěvě zoo: veřejnost je značně Ihostejná ke vzdělávacímu úsilí (Acampora, 2008), do zoo přicházejí za zábavou, ne vzděláním, před výběhy postojí sotva krátce, jsou zaujati především tím, co je roztomilé - mlád'aty (přehled výzkumů k motivaci Reading, Miller, 2007).

Kromě výzkumů, které se věnují kognitivní stránce, např. nakolik vzrostlo povědomí o příčinách ohrožení či znalost nějakého dalšího ohroženého druhu, se objevuje i literatura, která poukazuje na význam emocí, jež rovněž ovlivňují „učení ochranářství" (Ballantyne et al., 2007). Některé výzkumy k pozitivnímu emocionálnímu ovlivnění uvádí také Stausová, (2020). Výzkum emocionálního ovlivnění by mohl pomoci lépe objasnit, jaké zkušenosti ke změně postojů vedou, a jak zoo může působit. Bulbecková (2005) také dokládá, že osobní střetnutí s divokými zvířaty může mít hluboký emocionální dopad. V jejím výzkumu měli návštěvníci potěšení z hlazení koaly, krmení papoušků, nebo plavání s delfíny, tedy z autentického setkávání. Proto se přimlouvá za překonání dichotomie (dnes už, doufejme, samozřejmé) zábava - vzdělání, a za využití emocionální reakce na zvířata pro vybudování uctivého správcovství. Na podporu svého názoru cituje ústní projev Jakoba-Hoffa: "Ochranářství se neodehrává $v$ zoo, může ho být dosaženo jen změnami v lidské mysli, které mají za následek změny v chování" (Bulbeck 2005, s. 202).

Prováděné výzkumy jsou však převážně kvantitativní, což ve své studii Nygren a Ojalammi kritizují (2018). Může to být totiž důvod, proč nemohou doložit, zda zoo environmentální výchovu poskytuje. Proto celkový závěr, který z výzkumů až dosud vyplývá, kritiku z oblasti animal ethics neumlčel. Lori Gruen (2016) tvrdí, že důkaz prý není žádný. Ostatně, jak již bylo řečeno, zoo každoročně navštíví takové množství lidí, že jejich vliv by musel být znát na změně chování k přírodě. "Selhání" může být dáno i dalšími příčinami, např. neposkytnutím vodítka, jak k ochraně prírody přispět, informováním o vzdálených zemích, ne místních problémech (Staus, 2020). Andrew Moss, Eric Jensen a Markus Gusset (2017) vyjadřují ve studii vztažené $\mathrm{k}$ nárůstu znalostí o biodiverzitě a znalostí o tom, jak je možné přispět k ochraně, i další problém. Existující znalosti, které vzdělávací kampaň WAZY v r. 2014 dle této studie mírně podpořila, nevedou nutně ke skutečné změně v chování. Snad můžeme alespoň optimisticky uzavřít tím, že zoo přinejmenším pravděpodobně přispívají k existujícímu obecnému tlaku na změnu smýšlení a jednání. 


\section{Předává zoo návštěvníkům jiný vzkaz?}

Výzkumy efektu návštěvy zoo se zaměřují na důkaz pozitivního vlivu. Podívejme se nyní nejprve na možné negativní efekty, at už na základě výzkumů či interpretací smyslu působení, a posléze na odhadovaný pozitivní vliv. Otázku, čemu nás zoo ve skutečnosti učí (a do jaké míry je $\mathrm{k}$ tomu učení nutné držet zvírata $v$ zajetí) si kladl už Jamieson (1985). I bez znalosti dosavadních výsledků výzkumů, situace vyvolává etické otázky, co se učíme o lidsko-zvířecích vztazích, když vidíme divoká zvířata zavřená v klecích? Jaké postoje vưči zvířatům to podporuje? Předává se tak dětem adekvátní poselství, např., že jsou některá zvírata při střetnutí ve volné prírodě nebezpečná (medvědi, tygři, smrtelně jedovatí hadi)? Vede vidění zviŕat za ploty či skly k respektu, nebo naopak k pocitu nadřazenosti? Nepoškozuje vystavování, nebo cvičení zvírat jejich důstojnost, jak se domnívá Gruen (2011)? Co se učíme o prírodě? A co se učíme o tom, zda a jak může člověk pro svoje cíle zasahovat do života zviŕat?

Kellert (1979) svého času konstatoval, že mnozí návštěvníci odcházejí ještě přesvědčenější o naší nadřazenosti nad přirozeným světem. Některé novější studie s obdobnými výsledky uvádí Margodt (2010). I v současnosti dospívají autoři k závěru, že zoo předává, či ještě posiluje lidskou dominanci nad zvíretem, sklon k antropomorfizaci a odděluje ho od př́rody jako zachránce, toho, kdo se od přírody učí, návštěvníka, turistu (Nygren, Ojalammi, 2018). Podle Irus Bravermanové zoo posilují dualismus člověk - příroda představou, že Příroda je oblast nedotčená člověkem, někde tam venku (2013). V obraze, který nám zoo předává je člověk nad přírodou a oddělen od ostatních zviŕat a od mimo-lidské prírody, je hrozbou, nebo zachráncem, ochranu př́rody dělá někdo jiný, ne návštěvník, př́padně se odehrává někde jinde $v$ jiné zemi (Braverman, 2012). Tím, že se poselství zoo soustředí na exotické druhy a vzdálené země (také skrze výběr chovaných zvířat), nespojují se pro návštěvníka problémy s možností ovlivnit situaci v každodenních životech. Není sice jisté, zda stále platí, že návštěvníci zoo jsou lépe informováni o tropech, než o vlastní zemi a jejích ekologických problémech, jak to uváděl Hancocks v r.1995. Při nejmenším toto tvrzení zůstává výzvou jak pro manažery zoo, tak pro výzkumníky.

Ačkoliv zoo vyvíjejí ohromné úsilí vzdělat veřejnost v některých oblastech, není ani na první pohled, ani z výzkumů jisté, co si lidé z návštěvy zoo odnesou. Bulbecková (2010) varuje před možností, že při střetávání s divokými zvíraty mohou lidé také obdržet "špatný vzkaz" (např. nepochopení, že zviřata potřebují prostor, že zažívají stres, atd.). Stále častěji navrhovanou alternativou, která by měla predejít tomu, aby se poselství nestalo chybným, je střetávání s opuštěnými či zraněnými zviřaty v návštěvnických centrech. Tento typ střetnutí se zviŕaty Bulbecková interpretuje jako úspěšný regulátor jinak sobecké a ignorantské touhy krmit zvířata čímkoliv nevhodným.

Otázka, čemu nás zoo učí, zůstává velmi palčivou, jsme-li informováni o praxi zabíjení přebytečných, nebo k chovu nevhodných jedinců. Tato praxe byla dř́ve utajována, dnes se k ní některé zoo veřejně hlásí (medializovaný případ Copenhagen zoo). Praxi zabíjení nadbytečných zviŕat je v oblasti etiky možné chápat jako inherentní konflikt mezi snahou zachránit druhy, a péći o individua (Palmer et al., 2020). Zachraňujeme-li druhy způsobem, jakým to dělají zoo, dochází nevyhnutelně k poškozování zájmů individuí. Nejde jen o zabíjení geneticky nevhodných jedinců, mlád'at, pro která není umístění, ale také o přesuny zvířat do dalších zoo dle plánu geneticky vhodného chovu, a tím často k narušení emocionálních vazeb a vztahů jak k př́slušníkům druhu, tak k lidským pečovatelům.

Praxe zabíjení přebytečných zvírat bývá odůvodňována nápodobou prírody, záchrannými programy a nutností udržet genetickou variabilitu (např. Pluháček, 2020). $Z$ etického hlediska zde účel světí prostředky, chov zviřat se stává záležitostí technickou, manažerskou, a láska a péče se vytrácí (Cf. Emmerson 2020). Pochybnosti týkající se smysluplnosti snahy 
o záchranu druhů jsou vztaženy pochopitelně především $\mathrm{k}$ vršku potravního řetězce, pro něž již neexistuje odpovídající prostředí, kam by se zvírata mohla vrátit. Podle Keulartze (2017), který nepatří k přísným kritikům zoo, je dosavadní "úspěch" chovných programů pochybný, vyhlídky reintrodukčních programů jsou nízké, takže skutečnost zdaleka nedosahuje očekávání.

I když však připustíme, že zoo jsou schopny, či dokonce by měly (ve smyslu etického imperativu) některé druhy zachránit ${ }^{5}$, pak se vrací otázka, $k$ čemu je široká veřejnost přivykána? Dávají nám tím zoo najevo, jak se také, chceme-li být chovateli, můžeme chovat ke svým domácím mazlíčkům, tedy dát je usmrtit v prípadě, že se nám nebudou "hodit" do chovu? Má rozhodovat při výběru chovu druhů oblíbenost? Zoo totiž kromě těch zvířat, která jsou na červeném seznamu IUCN zařazena mezi ohrožené druhy, chovají i velké množství dalších, neohrožených zviřat, či tzv. charismatickou megafaunu, tedy zviŕata, která jsou návštěvnicky přitažlivá (Margodt, 2010; Hrdá, 2018). Nejvíce chované druhy jsou ty, které jsou obecně považované za nejkrásnější (Landová, Lišková, \& Frynta, 2014).

Přes uvedená upozornění na možný negativní vzdělávací efekt je potřeba uznat, že zoo se ve svém předpokládaném implicitním poselství začínají diverzifikovat: některé zmíněnými informacemi, které vytvářejí vodítko k vlastnímu jednání. Jiné již chovají handicapovaná zvířata. Zoo v Detroitu došla k rozhodnutí vzdát se z etických důvodů chovu slonů a poslala svoje dva slony do útulku ${ }^{6}$. Po př́kladu Zoo Detroit následovaly další. Jiné zoo naopak opět slony z divočiny dovezly (Gruen, 2016).

\section{V čem je další potenciál zoo ve vzdělávání?}

Dal Jamieson se v r. 1995 domníval, že zoo nás učí falešnému smyslu pro naše místo v prírodním řádu, že jen zvýrazňují rozdíl člověk - zviŕe (Jamieson, 1995). Podobně Ralph Acampora (2008) vykreslil zoo jako instituce, které byly původně mocným symbolem dominance, a z tohoto dědictví stále něco přetrvává. Zoo za poslední desetiletí prošly obrovskými změnami, jak v péči o zvířata, tak ve vztahu k návštěvníkům (Bayma, 2012, Roe, McConney, \& Mansfield, 2014). Prezentují se jako instituce s důležitým morálním posláním: záchranou druhů a environmentální výchovou. Přesto ne všichni s tímto hodnocením souhlasí. Jamieson (1995) svoji nesouhlasnou pozici vyjádřil tak, že moralita naopak vyžaduje, abychom se držení zvíratat v zajetí vzdali, protože jde daleko více o naši touhu (a naše uspokojení) zachraňovat druhy než o skutečně etické jednání. Dnes to někteří odborníci vidí obdobně (Marino, 2016), protože nejde o proměnu konkrétních zoo, ale o principy, na kterých zoo jako instituce stojí. Možnost, že by se tyto základní ideje změnily, že bychom si v dohledné době přiznali, že zviŕata držíme ve většině případů pro nás a naše potřeby, ne pro ně samotné, nebo že by se zoo prudce přeměnily $v$ útulky (jakým je např. Monkey World), je velmi malá. Proto je potřeba dále reflektovat vzdělávací roli zoo ve společnosti. Pokusím se zde načrtnout, $v$ čem spatřuji skutečnou potencialitu vzdělávání zoo, která není prozatím předmětem výzkumů.

Mezi zdánlivě okrajové účinky, ale ve skutečnosti významné a s dalekosáhlými důsledky, patří ovlivnění respektu ke zvíratům i jejich potřebám, zvýšení ohleduplnosti, empatie. Bulbecková (2010) věří, že je možné se něco takového naučit v zoo. Ostatně patří to i

\footnotetext{
${ }^{5}$ Tím je zde míněno nikoli držení částečně již domestikovaného druhu v zoo po blíže neurčenou dobu, ale úspěšná reintrodukce do existujícího vhodného prostředí, kde se druh dokáže dále reprodukovat bez pomoci člověka.

${ }^{6}$ Sloni jsou považováni za vysoce problematická zvířata k chovu; jejich welfare v zoo bude vždycky omezené s ohledem na potřebu pohybu a pevná emocionální pouta k ostatním členům rodiny.
} 
mezi doporučení WAZA: „Zoologické zahrady a akvária by měly propojit publikum s principy péče o zvířata a ukázat, jak jejich organizace dosahuje vysokých standardů životní pohody pro druhy v jejich péči" (WAZA 2020).

Mezi významné prvky péče o zviŕata a jejich potřeby patří tzv. enrichment7 ${ }^{7}, v$ jehož rozvoji některé zoo skutečně velmi pokročily, a ukazují tím návštěvníkům, že respekt ke zvíratům v lidské péči znamená vnímat dobře jejich potřeby a naplňovat je, že tedy ani zviŕ̌ecí společníky nemůžeme nechat ležet na gauči, ale poskytnout jim co nejlepší možné uspokojení potřeb, aktivizovat je. Pořád ale zůstává enormně velký prostor pro naplnění potřeb zvírat v možné míre a zlepšení ohleduplnosti ke zviŕatům. Pečovatelé o zviŕata si často stěžují na chování, které negativně zviřata ovlivňuje, jako bušení na sklo, př́liš velký hluk, nebo krmení. Zoo tento problém řeší snahou apelovat na emoce návštěvníků, či na jejich intelekt použitím různých značek nebo prítomností personálu v ubikacích (Collins et al., 2019). Avšak samy zoo se zatím neproměnily $v$ místa, která by nás učila tichému pozorování. Hlučná zábava jako jsou kolotoče umístěné uprostřed zoo pravděpodobně nepodporují postoj respektu $k$ potřebám zviŕat.

Podle výzkumů ovlivňuje hodnoty a postoje také uspořádání expozice (Reading, Miller, 2007). Proto $v$ duchu Acamporova požadavku, aby se zoo změnily z místa arogance na místa lásky a aby se zrušil exoticismus (Acampora, 2008), by pomohlo uzpůsobení ubikací a nastavení podmínek tak, aby se musel omezit návštěvník, nikoliv zvíře. Aby zviř̌e mělo prostor, kde se může schovat a nebýt stále na očích. To vše může vést $k$ většímu uvědomění, potřeb a svébytnosti zviŕat. „V zajetí můžeme respektovat dưstojnost zvířat tím, že jim dovolíme, aby byla viděna pouze tehdy, když si budou přát být viděna, a uznáme jejich životy jako jejich bez našeho souzení a vměšování" (Gruen, 2016, podobně Margodt, 2010).

Zoo by mohly být príkladem, jak se zviŕrecími individui citlivě a s respektem zacházet. To je ovšem zcela $v$ protikladu ke zmíněné praxi zabíjení přebytečných jedinců, zejména z hlediska plánů na udržení genetické variability, pokud nejde jen o krajní řešení. Zoo se hájí tím, že napodobují přírodní mechanismy (Pluháček 2020) a jde o řešení vhodnější než antikoncepce či kastrace. Srozumitelnost této praxe ovšem stojí na předpokladu, který nemusí být samozřejmý, totiž že zoo mají (etický imperativ), či mohou (reálně) hrát roli Noemových arch. ${ }^{8}$

Zvírata v zajetí ale nemají možnost žít život, jaký by žila v divočině. Jejich život, jejich volby, přežití na základě schopností či náhod, je naprosto změněn a zcela závislý na kultuře a našem způsobu zacházení. Zviŕatům v kultuře poskytujeme možnosti, jaké má člověk nemusí podléhat predaci, či smrti na choroby, kterým by šlo lékařskou péčí předejít. Na druhou stranu nemají možnost vlastní volby, např. výběru partnera nebo shánění potravy, čemuž mnohá zviŕata dávají přednost (Margodt, 2010). Tím, co jim poskytujeme, je vydělujeme z přírody stejně jako člověka. Pak je ovšem nekonzistentní na jedné straně o zviŕata pečovat, na druhé považovat jejich usmrcování za př́rodě podobný proces. Zoo jako veřejná místa svým jednáním ukazují, jestli jsou zviřata a jejich pohoda na prvním místě, nebo slouží jako reprodukční stroje cílům organizace. A jestli účel může posvětit prostředky.

\footnotetext{
${ }^{7}$ Enrichment představuje různé aktivity, které mají obohatit život zviřat a nahradit tak některé druhy deprivací dané uzavřením v neodpovídajícím a nepřirozeném prostředí. Nejčastějším druhem je schovávání potravy tak, aby zviŕe muselo vyvinout více úsilí dostat ji, oblíbené jsou i různé hračky, možnosti šplhání, ale třeba i zařízení vyluzující zvuky (klávesy pro vydry:

https://www.youtube.com/watch?v=wsRIO4dQJGI)

${ }^{8}$ Zde není prostor pro velmi širokou debatu na toto téma. Více k tomu např. Keulartz (2017), Emmermann (2020), Margodt (2000, 2010), Hrdá (2018)
} 
A konečně, nejde pouze o otázku, jestli zvírata strádají. Jde také o to, jestli prospívají, jestli mohou být jejich schopnosti plně rozvinuty, jestli podmínky, v nichž se odehrávají jejich životy, nepopírají jejich důstojnost, a neodepíráme tím zviŕatům základní spravedlnost (dle "capabilities aproach" Marty Nussbaumové, 2005). Zoo by mohly vzdáním se určitých druhů zviŕat ukázat chovatelům, že nejde primárně o chov jakéhokoliv zajímavého, nebo oblíbeného zviŕrete, které v podmínkách vysloveně netrpí, ale o chov a blízkost zvířat, jimž můžeme zajistit skutečný rozvoj jejich schopností, tedy že jde o zviŕăa samotná.

Další potencialitou pro vzdělávání, ke které se upírají také naděje zastřešujících organizací zoo, je vědomí souvislosti životního stylu a destrukce přírody. Asi si nemůžeme dělat iluze, že by jedna návštěva zoo změnila hodnotový žebříček a trvale ovlivnila postoje, které by vedly ke snížení konzumu, šetrnějšímu způsobu života a pocitu, že sebeomezení za účelem pomoci př́rodě je součást naší vlastní seberealizace $v$ intencích A. Naesse ${ }^{9}$ (1994). Ale samotná informovanost a uvědomění si souvislostí může otevř́t, připravit, zajistit ochotu přijmout strukturální opatření, možná i omezení, k nimž může v budoucnu dojít, pokud nechceme nadále žít pod heslem „po nás potopa".

Zoo mohou také informovat o možnostech jednotlivců přispět svým jednáním k prevenci, nebo ochraně. Uved'me zde několik příkladů již existujících informačních kampaní: např. informace o tom, jak se provoz domácnosti podílí na ekologických dopadech a jak je Ize zmírnit, jak Ize pomoci sovám vyvěšováním budek, informace vedoucí k uvědomění, že si sami špatně hospodaříme $s$ krajinou (vysazování monokultur, hnojiva a pesticidy $v$ zemědělství, či jak se podílíme svým kupováním výrobků s palmovým olejem na kácení pralesů.

Překážkou otevřeného informování se však stává sponzoring. Při návštěvě jedné zoo v ČR v r. 2015 jsem nalezla informační cedule o ohrožení žiraf v Africe zhruba o velikosti A5 (tedy poměrně malá na čtení) hned vedle obrovského kola z mahagonového dřeva s reklamou na firmu vyrábějící zárubně a dveře $z$ tohoto vzácného dřeva, kvůli jehož těžbě se kácí pralesy, a tím ničí biotopy zviŕat.

Úcta $k$ př́rodě a morální ohledy jdou při vědomí přičin a následků ruku v ruce $s$ hesly "méně je lépe", či "ke štěstí stačí málo", což je v prudkém kontrastu k hodnotám současné tržní společnosti. Konsumerismus a životní styl jsou témata vysoce citlivá, což může být pravděpodobným důvodem, proč se s tímto tématem setkáme jen ojediněle. "Nalézt řešení pro přelidnění a konzumerismus jsou politicky nepohodlné předměty. Výsledkem toho je, že ochranářství nezastavilo skluz vymírání" (Bradshaw, Marino, 2007, s. 25). Do zoo chodíme, jak ukázaly výzkumy, přeci především pro potěšení, ne si nepř́ijemně uvědomovat, že i způsob, jakým žijeme, významně přispívá k devastaci př́rody, a nejen naší.

Informační cedule $v$ zoo často uvádějí jako důvod ohrožení druhu kácení pralesů, ohrožení životního prostředí apod. Pokud mají mít tyto informace významný dopad na uvědomění a změnu, pak by bylo potřeba, aby zoo ukazovaly více a častěji, např. souvislosti mezi užíváním letecké dopravy a globální změnou klimatu, mezi turismem a ubýváním přirozeného prostředí, mezi výší konzumu, módou apod. a výrobou, dopravou, emisemi a odpadem. Bohužel, $v$ tomto bodě, je třeba dát za pravdu i všem, kteří namítnou, že $k$ tomu nepotřebujeme držet zviŕata $v$ zajetí, nicméně pokud zoo tuto roli na sebe vzaly, mohou významně přispět.

${ }^{9}$ Arne Naess je zakladatelem hlubinné ekologie, která staví na předpokladu, že důvodem, proč ničíme přirodu je, že si neuvědomujeme hluboké spojení s ní. Seberealizace by znamenala dosažení stavu, kdy i přírodu zahrnujeme do svého Já, a tudíž její zájmy jsou také našimi. 


\section{Etické i jiné implikace}

Dosavadní výzkumy o vzdělávacím přínosu zoologických zahrad nekorespondují se sebe-vyzdvihováním zoo jako míst, která hrají stěžejní úlohu ve vytváření ochranářského povědomí a tím $v$ záchraně druhů. $Z$ výzkumů se zdá, že zoo pravděpodobně oslovují již existující postoje člověka a jeho hodnoty. Mohou zesílit poselství o - pro daného návštěvníka - již dobře známých aktivitách. Nepřemluví ho však k novým (Smith et al., 2008). Zoo tedy mohou ve své současné podobě oslovit jak ty, kteří považují zviŕata za nižší tvory, kteří tu jsou k našemu použití a zábavě, tak ty, kteří jsou otevření ochraně i za cenu vlastního času, prostředků a námahy. Budou-li zoo i nadále existovat ve formě, jak je známe, je potřeba dále $v$ tomto ohledu realizovat výzkumy, které by pomohly pochopit, které okolnosti jsou nejpř́znivější pro ovlivnění pozitivních ochranářských postojů a otevření lidských srdcí zviŕratům. Doufejme však, že zoo budou spiše směřovat k hlubokým reformám a přeměnu v útulky, jak navrhuje bývalý dlouholetý ředitel zoo Detroit Ron Kagan (2016), což by znamenalo jiný druh vlivu.

Zda mohou zoo přinést návštěvníku i více, než bylo naznačeno $v$ části o potencialitách zoo, patří už do oblasti málo potvrzených úvah. Je zjevné, že minimálně u některých lidí a v některých situacích je setkání se zvířaty významné (Bulbeck, 2005), dotkne se člověka způsobem, který jej (snad nepřeháníme) pozitivně promění. Enormní popularita zoo po celém světě prý rovněž vnucuje předpoklad, že zoo odpovídají na nějakou silnou lidskou potřebu (Staus, 2020). Je dokonce možné, že je cosi hluboce pravdivého na různých tvrzeních, obvykle se objevujících ve spirituálním kontextu, že zvířata nás obdarovávají něčím neuchopitelným, že nám pomáhají v duchovním růstu, že se učíme soucitu a laskavosti. Slovy předního etologa Marca Bekoffa: „Co postihne zvířata, postihne nás. Blízký vztah k prírodě je kritický pro naše vlastní blaho a spirituální růst." (Bekoff, 2007, s. 162). To jsou ovšem věci, o kterých můžeme svědčit zkušenostně, nemůžeme však pro ně argumentovat analytickým rozumem, a zatím je ani dokazovat empiricky. Musíme se smírit s tím, že taková tvrzení dosud stojí mimo hranice vědy a vědecké metodologie. Rychle však dodejme, že i kdyby bylo tvrzení, že nás setkání s divokými zviřaty významně obohacuje, podpořené výzkumy, nemohlo by to být „povolenkou" pro jejich bezbřehé chovatelství. I nadále se domnívám, že držení divokých zviřă v zajetí je náš, lidský zájem, ne naše právo či snad dokonce etický počin.

\section{Závěr}

Zoo jsou významnou součástí života mnoha lidí, především dětí, a toto postavení dává zoo potenciál velkého vlivu na návštěvníky. Přestože jsou stále terčem kritiky těch, kteří se domnívají, že sama jejich existence nemá etické oprávnění, že divoká zviřata bychom neměli chovat, pokud nemůžeme naplnit jejich potřeby, existují a budou existovat i nadále, proto je důležité jejich roli reflektovat.

Akreditované zoo vyvažují kritiku za držení za divokých zviřat v zajetí cíli, které mají být něčím jako "vyšším dobrem" - záchrana druhů a vzdělávání. Zejména na environmentální vzdělávání je při současné ekologické krizi kladen velký dưraz. Stalo se tedy jak cílem akreditovaných zoo, tak také předmětem výzkumů.

Výzkumy zatím nepotvrdily, že by docházelo návštěvou zoo $\mathrm{k}$ významným změnám v postojích, hodnotách, či otevřenosti ke změnám v životním stylu. Kromě výzkumů zaměřených na pozitivní ovlivnění (povětšinou kvantitativní studie), uvádí literatura také některé negativní dopady, jako posílení antropomorfizace, pocitu dominance nad př́rodou, či pocitu oddělení od přirody. Problematická je z etického hlediska vzhledem k předání "vzkazu" návštěvníkům rovněž praxe spojená s tzv. záchranou druhů. 
Přes uvedené výhrady, chybějící evidenci, či skutečnost, že některé zoo se rapidně proměňují, spatřuji další významné možnosti ovlivňování a výchovy. Zoo mohou působit skrze primární ohled na životní pohodu individuí před jinými cíli, vzdáním se určitých druhů, jejichž životní pohoda nemůže být naplněna, skrze odvážnější informování o našem vlastním podílu na ohrožení zviřat, úbytku prostoru apod., a pobídkou, jak sami ve svých konkrétních situacích můžeme přispět ke změně. Tuto etickou reflexi by bylo vhodné rozvinout dalšími výzkumy, at́ už ohledem na pozitivní či negativní dopad návštěvy zoo.

\section{Poděkování}

Autorka děkuje Ivě Lelkové, Filipovi Jarošovi a anonymním recenzentům za podnětné komentáře $\mathrm{k}$ textu. Článek byl podpořen $\mathrm{z}$ dotace pro Specifický výzkum FF UHK pro rok 2019.

\section{Literatura}

- Acampora, R. (2008). Zoos and eyes: Contesting captivity and seeking successor practices. In S.J. Armstron \& R.G. Botzler (eds.), The Animal Ethics Reader, 501506. 2. vydání. Londýn, Routledge

- $\quad$ [AZA] Association of zoos and aquariums (ㄷ 1997-2021). Visitor demographics. In Association of zoos and aquariums [online]. Dostupné z: https://www.aza.org/partnerships-visitor-demographics [cit. 18.1.2021].

- Ballantyne, R., Packer, J., Hughes, K., \& Dierking, L. (2007). Conservation learning in wildlife tourism settings: Lessons from research in zoos and aquariums. Environmental Education Research, 13(3), 367-383.

https://doi.org/10.1080/13504620701430604

- Balmford, A., Leader-Williams, N., Mace, G., M., Manica, A., Walter, O., West, Ch., Zimmermann, A. (2007). Message received? Quantifying the impact of informal conservation education on adults visiting UK zoos. In A. Zimmermann at al. (eds.), Zoos in the 21st Century, 120-136. Cambridge: Cambridge University Press.

- Barney, E. C., Mintzes, J. J., \& Yen, C. F. (2005). Assessing knowledge, attitudes, and behavior toward charismatic megafauna: The case of dolphins. The Journal of Environmental Education, 36(2), 41-55. https://doi.org/10.3200/JOEE.36.2.41-55

- Bayma, T. (2012). Rational myth making and environment shaping: The transformation of the zoo. The Sociological Quarterly 53(1), 116-141. https://doi.org/10.1111/j.1533-8525.2011.01228.x

- Bekoff, M. (2007). The Emotional Lives of Animals. A Leading Scientist Explores Animal Joy, Sorrow, and Empathy, and Why they Matter. Novato, California: New World Library

- Bradshaw, G., Marino, L. (2007). Minds of their own: The exciting new field of trans-species psychology. Best Friends Magazine Nov./Dec.

- Braverman, I. (2012). Zooland: The Institution of Captivity. Stanford University Press. 
- Braverman, I. (2013). Conservation without nature: The trouble with in situ versus ex situ conservation. Geoforum 51,47-57. https://doi.org/10.1016/j.geoforum.2013.09.018

- Braverman, I. (2014) Captive for life. Conserving extinct in the wild species through ex situ breeding. In L. Gruen (ed.), The ethics of captivity. New York: Oxford University Press

- Bulbeck, Ch. (2005). Facing the Wild. Ecotourism, Conservation and Animal Encounters. London: Earthscan.

- Bulbeck, Ch. (2010). Respectful stewardship of a hybrid nature: The role of concrete encounters. In R. R. Acampora (ed.), Metamorphoses of the zoo: Animal encounter after Noah, 83-101. Plymouth: Lexington Books.

- Clubb, R. \& Mason, G. (2003). Captivity effects on wide-ranging carnivores. Nature 425(2) https://doi.org/10.1038/425473a

- Collins, C., Quirke, T., McKeown, S., Flannery, K., Kennedy, D., \& O'Riordan, R. (2019). Zoological education: Can it change behaviour? Applied Animal Behaviour Science [online]. 220 (104857), 1-10. Dostupné z: https://www.sciencedirect.com/science/article/abs/pii/S0168159119301200 [cit. 31.1.2020]. https://doi.org/10.1016/j.applanim.2019.104857.

- Emmerman, K. S. (2020). Moral arguments against zoos. In The Routledge Handbook of Animal Ethics, s. 381-393. New York and London: Routledge.

- Falk, J. H., Reinhard, E. M., Vernon, C. L., Bronnenkant, K., Deans, N. L., Heimlich, J. E. (2007). Why Zoos \& Aquariums matter: Assesing the impact of visit to a Zoo or Aquarium, In Association of Zoos and aquariums [online]. Dostupné z: https://www.aza.org/uploadedFiles/Education/why zoos matter.pdf ; [cit. 7. 2. 2018].

- Gruen, L. (2011). Ethics and animals: An introduction. Cambridge: Cambridge University Press.

- Gruen, L. (2016). Shifting toward an ethics of sanctuary. In Center for Humans \& Nature [online]. Dostupné z: https://www.humansandnature.org/shifting-towardan-ethics-of-sanctuary [cit. 27.1.2021]

- Hancocks, D. (1995). Lions and tigers and bears, oh no!. In B.G. Norton \& M. Hutchins (eds.), Ethics on the Ark. zooS, Animal Welfare, and Wildlife Conservation (31-37), Washington and London, Smithsonian Institution Press.

- Hancocks, D. (2001). A Different Nature. The Paradoxical World of Zoos and Their Uncertain Future. London, University of California Press

- Hrdá, M. (2018). Jsme tím, jak zacházíme se zviŕaty. Filosofický časopis 66(6), 909-933.

- Hutchins, M., Smith, B. \& Allard, R. (2008). In defense of Zoos and Aquariums: The ethical nasis for keeping wild animals in captivity. In Armstrong, S. J. Botzler - R. G. (eds.), The Animal Ethics Reader. 513-521. 2. vydání. London and New York, Routlege. 
- Jamieson, D. (1985). Against Zoos. In P. Singer (ed.), In Defense of Animals, 108117, New York: Basil Blackwell.

- Kagan, R. (2016). The show is over. In Center for Humans \& Nature [online]. Dostupné z: https://www.humansandnature.org/the-show-is-over [cit. 9.3.2021]

- Kellert, S.R. (1979). Zoological parks in American society. In American Zoo Association Annual Meeting Procedures (pp. 82-126).

- Keulartz, J. (2017). Ethics of the Zoo, In Oxford Research Encyclopedia of Environmental Science, e-ISBN: 9780199389414.

- Landová, E., Lišková, S., \& Frynta, D. (2014). Je krása vstupenkou na archu Noemovu? In O. Dadejík, F. Jaroš, \& M. Kaplický (eds.), Krása a zvíře. Studie o vztahu estetických a etických hodnot zvírat, 33-102. Praha: Dokořán.

- Mann-Lang, J. B., Ballantyne, R., \& Packer, J. (2016). Does more education mean less fun? A comparison of two animal presentations. International Zoo Yearbook, 50 (1), 155-164. https://doi.org/10.1111/izy.12114

- Maple, T., McManamon, R. \& Stevens, E. (1995), Defining the good Zoo. Animal care, maintenance and welfare. In Norton, B. G., Hutchins, M. (eds.), Ethics on the Ark. zooS, Animal Welfare, and Wildlife Conservation, (219-234). Washington and London: Smithsonian Institution Press.

- Marino, L. (2016). Emphasizing animal well-being and choice: why zoos and aquarium should become sanctuaries. In Center for Humans \& Nature [online]. Dostupné z: https://www.humansandnature.org/emphasizing-animal-well-being-andchoice. [cit. 17.1.2021]

- Marino, L., Lilienfeld, S., O., Malamud, R., Nathan N., \& Brogliod, R. (2010). Do Zoos and Aquariums promote attitude change in visitors? A critical evaluation of the American Zoo and Aquarium study. Society and Animals 18, 126-138. https://doi.org/10.1163/156853010X491980

- Margodt, K. (2000). The Welfare Ark: Suggestions for a Renewed Policy in Zoos. Brussels: VUB University Press

- Margodt, K. (2010). Zoos as welfare arks? Reflection on an ethical course for zoos. In R. R. Acampora (ed.), Metamorphoses of the zoo: Animal Encounter after Noah, 11-36. Plymouth, Lexington Books.

- Martens, P., Hansart, C., \& Su, B. (2019). Attitudes of young adults toward animals-the case of high school students in Belgium and The Netherlands. Animals, 9(3), 88, 1-12. https://doi.org/10.3390/ani9030088

- Moss, A., Jensen, E., \& Gusset, M. (2017). Impact of a global biodiversity education campaign on zoo and aquarium visitors. Frontiers in Ecology and the Environment, 15(5), 243-247, https://doi.org/10.1002/fee.1493

- Naess, A. (1994). Ecosophy T: Deep versus shallow ecology. In L. P. Pojman (ed.). Environmental Ethics. 105-112. Boston: Jones and Barlett Publisher.

- Nussbaum, M., C. (2005). Beyond "compassion and humanity". Justice for nonhuman animals. In C. R., \& Nussbaum, M. C. (Eds.). Animal rights: Current debates 
and new directions. Oxford University Press.

https://doi.org/10.1093/acprof:oso/9780195305104.003.0015

- Nygren, N., V., Ojalammi, S. (2018). Conservation education in zoos - a literature review. TRACE :: Finnish Journal for Human-Animal Studies 4, 62-76. https://doi.org/10.23984/fjhas.66540.

- Palmer, C., Morrin, H., \& Sandøe, P. (2020) Defensible Zoos and Aquariums. In The Routlege Handbook of Animal Ethics. 394-406. London and New York, Routlege.

- $\quad$ [PETA] People for the ethical treatment of animals (@ 2021). More info on animals used for entertainment [online]. In PETA [online]. Dostupné z:

https://www.peta.org/issues/animals-in-entertainment/animals-in-entertainment4/ [cit. 24.2.2021]

- Pluháček, J. (2020). Regulace populací v zoo. Prezentace na konferenci Podíl zoologických zahrad při environmentálním vzdělávání a osvětě, 3.12.2020 v Ostravě

- Reading, P. R., \& Miller, B. J. (2007). Attitudes and attitude change among zoo visitors. In A. Zimmermann at al. (eds.), Zoos in the 21st Century, 63-91. Cambridge: Cambridge University Press.

- Regan, T., (1995). Are Zoos morally defensible? In Norton, B. G. \& Hutchins, M. (eds.), Ethics on the Ark. zooS, Animal Welfare, and Wildlife Conservation, 38-51. Washington and London: Smithsonian Institution Press.

- Roe, K., McConney, A., \& Mansfield, C. F. (2014). The role of zoos in modern society. A comparison of zoos' reported priorities and what visitors believe they should be. Anthrozoös 27(4), 529-541. https://doi.org/10.2752/089279314X14072268687808

- Smith, L., Broad, S., \& Weiler, B. (2008). A closer examination of the impact of zoo visits on visitor behaviour. Journal of Sustainable Tourism. 16 (5), 544-562. https://doi.org/10.1080/09669580802159628

- Staus, N. (2020). The educational value of zoos. In The Routlege Handbook of Animal Ethics, 367-380. London and New York, Routlege.

- [WAZA] World Association of Zoos and aquariums (2020). Social change for conservation - The World Zoo and Aquarium conservation education strategy. In World Association of Zoos and aquariums [online]. Dostupné z: https://www.waza.org/wp-content/uploads/2020/10/10.06 WZACES spreads 20mbFINAL.pdf [cit. 28.1.2021] 